Research, part of a Special Feature on The influence of human demography and agriculture on natural systems in the Neotropics

\title{
Coca and Colonists: Quantifying and Explaining Forest Clearance under Coca and Anti-Narcotics Policy Regimes
}

\author{
Andrew V. Bradley $^{1}$ and $\underline{\text { Andrew C. Millington }}^{2}$
}

\begin{abstract}
The impacts of coca cultivation and coca eradication on rates of humid tropical forest clearance were examined in the agricultural colonization zone of Chapare, Bolivia. Using satellite imagederived land-use maps, interviews with farmers, and analyses of economic data and policy documents, forest clearance rates were analyzed in three contrasting communities from 1963 to 2003. Deforestation rates were very low from the late 1970s to the early 1990s when coca cultivation was widespread and anticoca policies were weakly enforced. Before and after this period, deforestation rates were significantly higher. This study provides the first detailed quantitative analysis of deforestation rates under different policy regimes in a coca source region. It provides weak support for the argument that labor constraints lead to a reduction in forest clearance rates during periods of coca cultivation advanced by Kaimowitz (1997); but stronger support for Henkel's (1995) hypothesis that farmers would clear large areas of forest after abandoning coca to maintain household incomes. However, economic arguments based on household data alone are inadequate in explaining forest clearance in this region, and a political ecological approach that analyses economic drivers in a policy framework provides better explains deforestation dynamics.
\end{abstract}

Key Words: anti-narcotics policies; Bolivia; coca; deforestation; forest clearance rates; land-use change

\section{INTRODUCTION}

Lowland tropical forests along the eastern margins of the Andes (the Tropical Andes biodiversity hotspot: Myers 1988, 2003, Myers et al. 2000) have witnessed waves of migrants during the late $20^{\text {th }}$ Century who have converted forest to cropland and pasture. Aided by a plethora of policy initiatives, they are fragmenting lowland humid and lower montane tropical forests; threatening habitat integrity; compromising ecosystem services; and impacting their own livelihoods and those of indigenous people. These phenomena have been mapped in Colombia (Viña et al. 2004, Etter et al. 2006), Ecuador (Walsh et al. 2003, Pan et al. 2004), Peru (Naughton-Treves 2004), and Bolivia (Steininger et al. 2002, Millington et al. 2003, van Gils and Loza Armand Ugon 2007).

Since the late 1970s, an important income source for many colonists has been coca-Erythroxylum novogranatense (D. Morris) Hieron. var. novogranatense in Colombia (MacGregor 1993, Fjeldså et al. 2005) and Erythroxylum coca Lam. var. coca in Bolivia (South 1977, Sanabria 2004) and Peru (Young 2004). Traditionally coca leaves have been chewed in the Andes (Commission of Enquiry on the Coca Leaf 1949, Meruvia 2000), but they are also the base ingredient for cocaine paste (MacGregor 1993). Since the 1970s, rising demand for cocaine in the developed world (Walsh 2004) has maintained high prices for coca relative to other crops, making it a lucrative cash crop. Perceived negative social impacts of coca chewing stimulated the UN Commission of Enquiry on the Coca Leaf in the 1940s (Commission of Enquiry on the Coca Leaf 1949). High levels of cocaine production and trafficking in South America by the late 1950s prompted the Interamerican Conference on the Illicit Traffic in Cocaine and Coca Leaves in 1960 and subsequent legislation (Parreiras 1961). Continued production and trafficking (Joseph Rowntree Foundation 2000, Steinberg et al. 2004) forced the U.S. government to initiate the "War on 
Drugs" and the enforcement of anti-coca policies during the 1980s and 1990s (McCoy 2004), which included uprooting and burning bushes, spraying defoliants, and introducing alternative development programs that promote substitute crops. Amazon deforestation caused by ranching and crop cultivation have been described and modeled elsewhere (e.g., Moran et al. 1994, McCracken et al. 1999, Mäki et al. 2002, Walker 2004); however, in the presence of illegal coca, agents and drivers of deforestation are also influenced by coca cultivation, cocaine processing, and policies designed to counteract coca-related activities (Bradley and Millington 2008). Social and political issues related to coca have generated much research, but little attention has been paid to environmental impacts. These include deforestation, forest fragmentation, encroachment onto conservation units, soil erosion, and point pollution of soil and water (Dourojeanni 1992, MacGregor 1993, Young 1996). The enforcement of anti-coca policies further degrades environments in coca-source regions, e.g., defoliants contaminate soil (MacGregor 1993), streams, and groundwater.

Kaimowitz (1997) theorized that deforestation rates would be low under coca-dominated production systems because of the high labor requirements needed to maintain more than a hectare of coca bushes. Henkel (1995) presented a theoretical, economic argument based on calculations of cultivated areas in Chapare. He argued that without coca cultivation only $20 \%$ of farmers could be supported on the 114000 ha of land cleared by 1990 , and to support the remaining four-fifths, 700000 ha of forest would have to be cleared. This equated to an average expansion of each farm from a few to 20 ha. To our knowledge, no detailed, quantitative analysis of deforestation rates under coca production and anti-coca policy regimes has been published.

\section{STUDY AREA}

The Chapare colonization zone covers approximately $24500 \mathrm{~km}^{2}$ of central Bolivia (Fig. 1) and, after parts of Colombia and Peru, it is the third largest cocasource region globally United Nations Office on Drugs and Crime (UNODC 2006). Elevation ranges from 200-500 m.a.s.l. and, before colonization, it comprised terra firma and inundated lowland forests on alluvial fans and seasonally inundated floodplains (Montes de Oca 1989). The region is connected by road to the second (Santa Cruz) and third (Cochabamba) largest urban areas in Bolivia: both are major markets for Chapare's produce. The Andes, to the south, are covered with species-rich, tropical montane forests containing high levels of endemism. Chapare forms a transition zone between biologically important Andean montane forests and the Amazonian humid tropical lowland forests to the north (Myers 1988, Myers et al. 2000, Navarro et al. 2004), and biological interchange between the two is compromised by development in Chapare.

Colonization began in 1910 at Todos Santos in central Chapare. The first government-sponsored schemes were initiated in the same area a decade later (Lavandez 1925, Weil 1983). Until the 1960s, colonization was generally unsuccessful (Mather 1922, Crist 1946, Weeks 1946, Edelmann 1967, Fifer 1967, Weil 1983). However, during the 1960s, several hundred communities and some large-scale commercial ventures were established in central Chapare under Plan Decinal. They caused forest destruction that has been attributed to farmers inexperienced in humid tropical environments and weak government support (Rivera 1990). Driven by national shortages of potatoes and maize, colonists invested in rice, leading to rapid deforestation (Weil and Weil 1983). By the 1970s, fruit cultivation and ranching were commonplace. At this time, coca, which grows well in Chapare and is easy to transport as dried leaves, had become popular, although Rodriguez (1965) noted it was cultivated in the late 1950 s and early 1960s. During the 1980s, colonization shifted to eastern Chapare along a new road linking Cochabamba and Santa Cruz (Millington et al. 2003). Improvements in transport infrastructure should have favored the growth of marketable, perishable crops, but coca continued to dominate because of the high prices created by strong global demand for cocaine (Bostwick et al. 1990). Coca production became so prevalent that the United States forced the Bolivian government to implement anti-narcotics policies (Sanabria 2004). To comply with U.S. policies, the Bolivian government set coca-field destruction targets that were accompanied by increasingly aggressive eradication campaigns conducted by the Bolivian police and military during the 1980s and 1990s (Morales 2004) (Table 1). Law 1008 (Ley del Regimen de la Coca y Sustancias Controladas) in 1988 recognized legal cultivation in traditional coca-growing areas in subtropical valleys of the Andes and made cultivation in the Chapare lowlands illegal. Subsequent anti-coca packages 
Fig. 1. Chapare: location map.

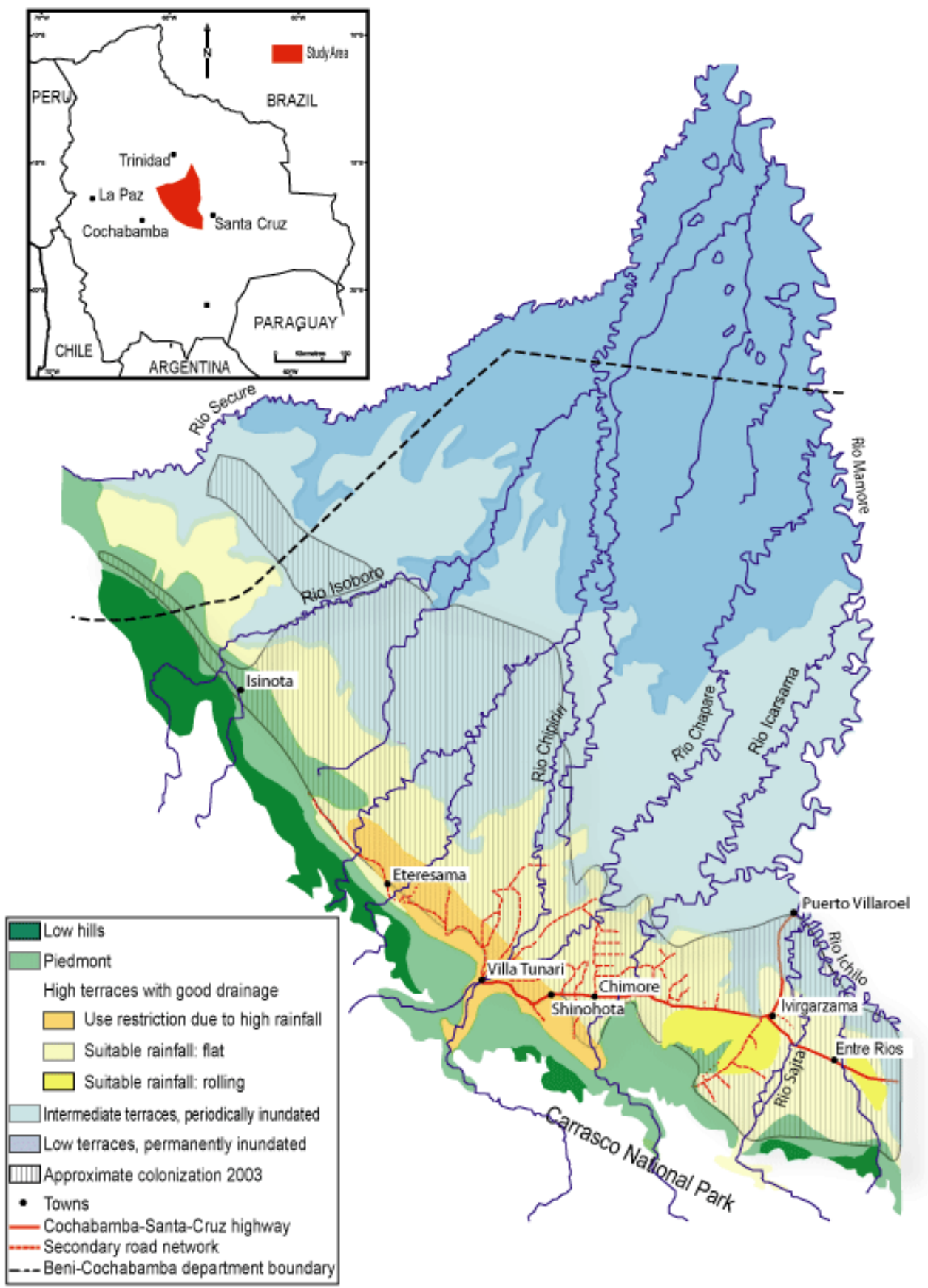


included alternative development programs built around crop substitution programs supported by U. S. Agency for International Development (USAID) marketing campaigns and subsidies (Table 2). Many substitute crops failed to reward farmers adequately because of: (i) lower economic returns than those from coca; (ii) poorly researched markets; (iii) markets that became oversaturated and crashed (Hellin 2001); and (iv) lower economic returns for substitute crops than anticipated because of middlemen-dominated transport networks and wholesale markets. These factors undermined confidence in substitute programs generally (Jackson et al. 2003), and in spice and palm heart cultivation specifically (Hellin 2001). Returning to coca was a common response.

\section{METHODS}

We used similar methods to Rindfuss et al. (2003). They included a time series of satellite images, household and farm surveys, and analyses of archived cadastral surveys, agricultural statistics, and economic data. Our time frame was 1963 to 2003. We selected three distinctly different communities in central and eastern Chapare that were colonized at different times (Table 3) for detailed analysis. Each represents one of the main types of agricultural activity in the zone. Their names have been changed to Communities I, II, and III, which also refers to the chronological order of settlement.

Land use and forest conversion were mapped from a time series of Corona, Landsat MSS, TM and ETM+ satellite images. Corona data are panchromatic high spatial resolution declassified U. S. spy satellite photographs acquired between 1959 and 1980, which have begun to be used to extend land-change studies backward into the 1960s (Hamandawana et al. 2007, Tappan et al. 2000). We used Corona KH4A data acquired on 23 September 1966 (ground resolution $\approx 3 \mathrm{~m}$ ) for Community $\mathrm{I}$. Cloud-free Landsat data for Communities I and III (Path/Row 232/72) were acquired on 1 July 1976, 4 October 1986, 18 July 1993, 18 February 1996, and 14 July 2000; and for Community II (Path/Row 231/72) on 16 September 1975, 25 July 1986, 9 July 1992, 5 August 1996, and 5 June 2000. We georectified the images (RMS $<0.3$ pixels) and mapped 10 land-cover classes using the ISODATA clustering algorithm in Erdas Imagine (Bradley
2005). We masked water bodies and shadow, and excluded them from the analysis. We used information obtained during field verification campaigns and interviews with farmers to allocate each cluster class to either a forest or a non-forest class for each image in the series. When we could not resolve a cluster class on the basis of this information, or contextually, it was allocated to forest. A forest/non-forest map was created for each year in the image sequences. Because we allocated ambiguous land covers to the forest class, forest clearance metrics are conservative and deforestation rates may be slightly underestimated. We digitized cadastral plans for each community and overlaid them on the forest/non-forest maps. We calculated forest and non-forest areas from each image map, and the proportions of forest remaining in ArcGIS. Rates of forest loss were calculated for inter-image periods using the following equation:

$r_{j}=\left(C A_{j}^{k 1}-C A_{j}^{k 2}\right) /\left(k^{1}-k^{2}\right)$

where $r=$ rate of clearance, $C A=$ cleared area, $j=$ community and $k=$ time point. Rates of forest clearance are assumed constant between image dates.

We conducted household surveys in each community in 2000 and 2003 . These focused on past and current land uses, with forest/non-forest maps being used as prompts. Cultivating coca in Chapare is clandestine, and talking to farmers about it is challenging. Therefore, we did not broach the subject until we had gained their confidence. It is too risky to enter farms without an invitation or an escort, so only if a farmer agreed did we walk their farms with them. Even then, we did not make detailed maps of coca cultivation using GPS during field visits as this would have jeopardized our research. Rather, they drew sketch maps of their past and current land uses, recording locations of specific crops and agroforestry complexes. We compared the sketch maps with the forest/non-forest maps to verify past forest cover and land use, i.e., to convert them to land-use maps. Some cropped areas were clear on the imagery, but others were less so because they were intercropped or overgrown.

We interviewed 14 of 110,16 of 90 , and 13 of 60 households in Communities I, II, and III, respectively, to provide information pertinent to Kaimowitz's (1997) labor argument. Using interview data and land-use maps, we created chronologies of dominant farming activities for 
Table 1. Main periods during which military action was used to enforce anti-coca policies (sources: Cardozo et al. 1999, Ortuño 2002, Jackson et al. 2003)

\begin{tabular}{lll}
\hline \hline Year(s) & Policy instrument & Enforcement action \\
\hline 1981 & $\begin{array}{l}\text { Law } 18265 \\
\text { Law } 18741\end{array}$ & $\begin{array}{l}\text { Option of compensation when coca crop forfeited, otherwise forced removal of coca } \\
\text { crop when discovered }\end{array}$ \\
1986 & $\begin{array}{l}\text { Operation blast } \\
\text { furnace }\end{array}$ & $\begin{array}{l}\text { Military strike unit targets localized areas to destabilize local economies based on } \\
\text { coca. }\end{array}$ \\
$1986-1989$ & Plan Trienial & $\begin{array}{l}\text { Intense military action to eradicate coca-abandoned after } 12 \text { months due to civil } \\
\text { unrest. }\end{array}$ \\
1988 & Law 1008 & $\begin{array}{l}\text { Legalization of } 12 \text { 000 ha of coca for cultural purposes-mainly in the Yungas of La } \\
\text { Paz. Coca bushes in the remaining areas to be removed within } 8 \text { years. } \\
\text { Five-year plan to remove all illegal coca-this target was claimed to be met in 2000. }\end{array}$ \\
\hline Plan Dignidad
\end{tabular}

each community (Fig. 2). We divided the 43 farms researched into six forest clearance typologies (e.g., Figs. 3 and 4), which were based on analyses of the trajectories of farming activities obtained from interviews and farm walks, and then identified the rates of clearance associated with each typology to define them in terms of land-use trajectories and rates of forest loss.

We obtained economic data from USAID. These are discontinuous as a result of short-term program funding, and are only available for the last two decades. Data from the Chapare Regional Development Project (CORDEP; 1993-1996) is for wholesale prices of substitute crops in the major cities. Price data on alternative crops (2001-2003) from the Counter-Narcotics Consolidation of Alternative Development (CONCADE) program were collected at truck checkpoints on the borders of Chapare. We also obtained data on farmgate prices during interviews, and time-series of coca prices and areas of under coca cultivation from the Bolivian National Statistics Institute (INE) and the UNODC. These data were used to contextualize trends in dominant farming activities and forest clearance rates, and test Henkel's (1995) ideas on comparative prices and clearance.

\section{RESULTS}

Forest areas and rates of forest clearance are shown in Fig. 2. Complete forest cover in Community I in 1963 had declined to $33 \%$ by 1986, although it had recovered to $44.8 \%$ by 2000 . In Community II, forest cover declined from complete cover before colonization (1972) to $42.8 \%$ by 2000 . Over the same time, forest cover in Community III fell from complete cover to $53 \%$.

Table 4 shows the proportion of farmers interviewed undertaking the main commercially oriented farming activities (banana, citrus, and coca cultivation, and ranching) in each community in relation to clearance statistics. In Community I, which was founded as part of a governmentsponsored settlement program in 1963, interviews indicate that subsistence dominated during the first 3 years, supporting Henkel's (1987) and Rivera's (1990) observations. Cultivation of rice (for subsistence and sale), a series of failed crops in the 1960s and 1970s, and coca in the late 1970s increased forest clearance rates (Weil and Weil 1983). Interviews indicate that at least half the farmers had cultivated bananas since the mid 1970s. This had increased to approximately three-quarters by 2003 . Coca cultivation gradually increased, and the greatest proportion of farmers (28.6\%) cultivated it during the mid 1990s. In the early 1990s, the clearance rates decreased as coca 
Table 2. Duration and aims of alternative development programs used as part of anti-coca policies (sources: Bostwick et al. 1990, Ortuño 2002, Jackson et al. 2003). CDRP = Cochabamaba Regional Development Program; CORDEP = Chapare Regional Development Project; CONCADE = Counter-Narcotics Consolidation of Alternative Development Program.

\begin{tabular}{|c|c|c|}
\hline Years & Project & Aims \\
\hline 1984-1987 & CDRP & $\begin{array}{l}\text { Research and development into alternative crops to coca. Creation of micro regions } \\
\text { around growth poles. }\end{array}$ \\
\hline 1987-1990 & CDRP (amended) & $\begin{array}{l}\text { Concentrated resources into Chapare region, involved crop substitution and research } \\
\text { and development into over } 40 \text { substitute crops. }\end{array}$ \\
\hline 1991-1999 & CORDEP & $\begin{array}{l}\text { Marketing and subsidizing of a few specific coca alternatives, e.g., palm hearts, } \\
\text { bananas, and pineapples (determined from the results of CRDP), coined "economy } \\
\text { substitution." }\end{array}$ \\
\hline 1999-2004 & CONCADE & $\begin{array}{l}\text { Support for Plan Dignidad, aimed at encouraging alternatives and stabilize } \\
\text { alternative markets to coca bushes as they were eradicated. }\end{array}$ \\
\hline
\end{tabular}

cultivation increased and farmers often abandoned other crops to maintain coca. Substitute crops increased as coca fields were eradicated and farmers were exposed to USAID substitute crop programs. Accordingly, there were increases in banana and citrus cultivation as farmers abandoned coca: between 1997 and 2000, forest clearance rates decreased further.

Most farmers in Community II settled in 1983 to form a cattle cooperative (Table 3 ), nonetheless between 1981 and 1995, a high proportion (34\%$62 \%$ ) grew coca. That proportion fell, and by 2000 , when only $12 \%$ admitted cultivating it, most (94\%) were clearing forest for pasture. Rates of clearance were highest immediately after the two periods of settlement, in 1972 (due to rice cultivation) and 1983 (due to subsistence crops, coca, and pasture). The relationships between the rates of forest clearance and the proportion of farmers cultivating coca or ranching are not clear; however, the greatest increase in the mean cultivated area occurred between 1987 and 1993 when an additional 44\% of farmers began to clear forest for pasture.

It is clear from the data in Table 4 that high rates of forest clearance were prevalent in Community III between 1983 and 1986 when farmers who had recently moved there cleared forest to grow subsistence crops and coca. After 1990, the proportion of farmers engaged in coca decreased. This was mirrored by an increase in the proportion of farmers cultivating substitute crops, which in this community were dominated by bananas. This switch occurred because farmers were forced to find alternatives to coca, and had joined USAID substitute programs. The relationships between forest clearance rates and periods of coca cultivation and substitute crops are clearer in Community III than in the other communities (Table 4).

In general, where coca was cultivated, forest clearance rates tended to be low, but increased as coca substitutes became dominant. Clearance rates were normally high when cattle ranching was the major activity. Some clearance typologies of the six identified (Table 5) were more frequent that others, e.g., in Community III, $76.9 \%$ of farms had trajectory 4 , coca to substitutes with slow to fast clearance, and in Community II, $62.5 \%$ of ranches were predominantly for cattle, with a period of coca when forest was cleared more slowly.

\section{DISCUSSION}

The analysis of forest/non-forest maps combined with interviews enabled contemporary and past land uses to be established. We contextualized these by 
Table 3. Salient information concerning the three communities studied (adapted from Millington and Bradley 2008). Note, in previous publications, the communities have been given the names of Caracas (I), Bogotá (II), and Arequipa (III).

\begin{tabular}{lcccccc}
\hline \hline Community & Area (ha) & $\begin{array}{c}\text { Altitude (m. } \\
\text { a.s.1.) }\end{array}$ & $\begin{array}{c}\text { Number of } \\
\text { properties }\end{array}$ & $\begin{array}{c}\text { Number and \% } \\
\text { of farmers } \\
\text { interviewed }\end{array}$ & $\begin{array}{c}\text { Year of } \\
\text { first settled }\end{array}$ & $\begin{array}{c}\text { Prevailing economic activities } \\
2000-2003\end{array}$ \\
\hline Community I & 1745 & 220 & 110 & $14(13 \%)$ & 1963 & $\begin{array}{l}\text { Banana, mandarin, and orange } \\
\text { cultivation }\end{array}$ \\
Community II & 3196 & $250-350$ & 90 & $16(18 \%)$ & 1972 & Ranching: beef and dairy \\
Community III & 1220 & 250 & 60 & $13(22 \%)$ & 1983 & $\begin{array}{l}\text { Banana, black pepper, } \\
\text { cassava, heart of palm, and } \\
\text { rice cultivation }\end{array}$ \\
\hline
\end{tabular}

reference to the time-series of crop price data to develop an understanding of the economic rationales behind farmers' decisions to clear forest at different rates under coca and anti-coca regimes. Coca prices between 1979 and 2002 are provided in Fig. 5. Although coca prices were at their lowest between the mid 1980s and the late 1990s, the farmers we interviewed strongly argued that risks associated with illegal coca cultivation during the period of low prices were worth taking because coca provided a better selling return than other crops. In part this is because, regardless of price, coca can provide three harvests a year in Chapare unlike most other crops.

To help develop this economic argument further, wholesale prices for pineapple, a major substitute crop, between 1992 and 2003 are shown in Fig. 5. The gaps in these data emphasize the difficulties in acquiring data on crop production and prices in Bolivia. Unlike coca, pineapple only provides one crop a year. The investments in pineapple are worse still compared with coca because the first harvest is delayed until 2 years after planting, after which fields are converted to other land uses. Pineapple prices also have a well-developed seasonal trend unlike coca, which maintains a more-or-less consistent price throughout the year. Peak prices for pineapple declined significantly between the mid 1990s and 2000-2003. It is thought that this was the result of market controls through subsidies. Subsidies also led to stabilization of banana prices between 2000 and 2003 compared with the mid 1990s (Fig. 5) when, although prices increased, their behavior was spiky. Compared with pineapples and bananas, a major advantage that stable coca prices gave farmers, even when coca prices were low, was a predictable, assured household income. We argue this led to the development of risk-adverse behavior amongst farmers, which made them reluctant to take risks with substitute crops later unless they could be assured of a secure market or a crop subsidy. The strongly advantageous selling returns of substitute crops reinforced this risk-adverse mentality.

These economic arguments are highly pertinent to our consideration of deforestation rates under coca and anti-coca regimes. In the theoretical example provided in Table 6 it is clear that the high economic returns of coca would not only strongly influence a farmer's decision to grow coca, but would impact on the amounts of forest that would need to be cleared to grow coca or a substitute crop. In the example, 14 ha of palm need to be grown to produce palm hearts equal in monetary value to a hectare of coca. These data strongly indicate that farmers would generally choose to cultivate coca over substitute crops because of its higher selling return and its relative stability compared with the unstable prices and markets for most substitute crops.

However, this has not been the case all the time in Chapare. The economic arguments above generally only apply when Chapare was under a coca regime, 
Fig. 2. Inter-image forest clearance rates (histograms) in ha/yr and proportions of forest remaining (line graphs) for Community I (top), Community II (middle), and Community III (bottom) between 1963 and 2000. The dominant land management tendencies are given for each community: HTF-humid tropical forest (no cultivation); $\mathrm{Sb}$-subsistence; $\mathrm{C}$-coca; $\mathrm{AD}$-alternative development programs (substitute crops); R-rice; P-pasture; F-fruit.

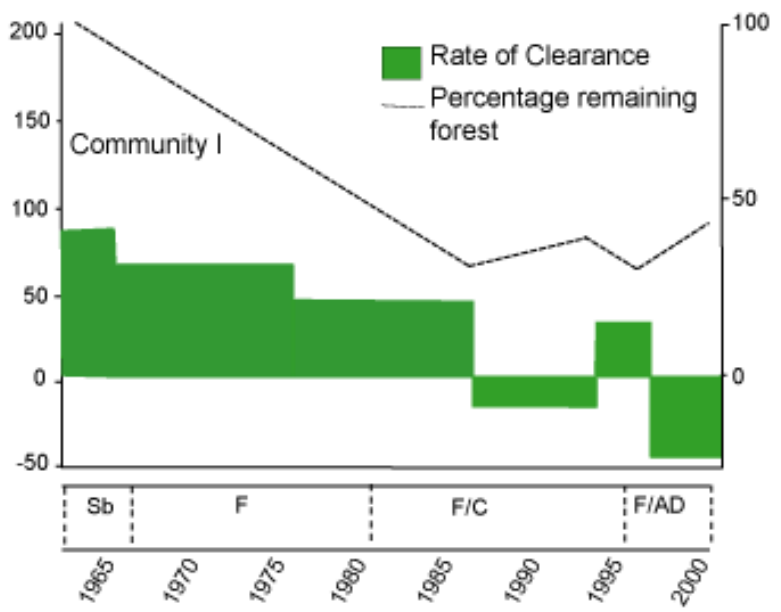

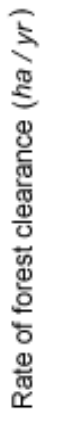
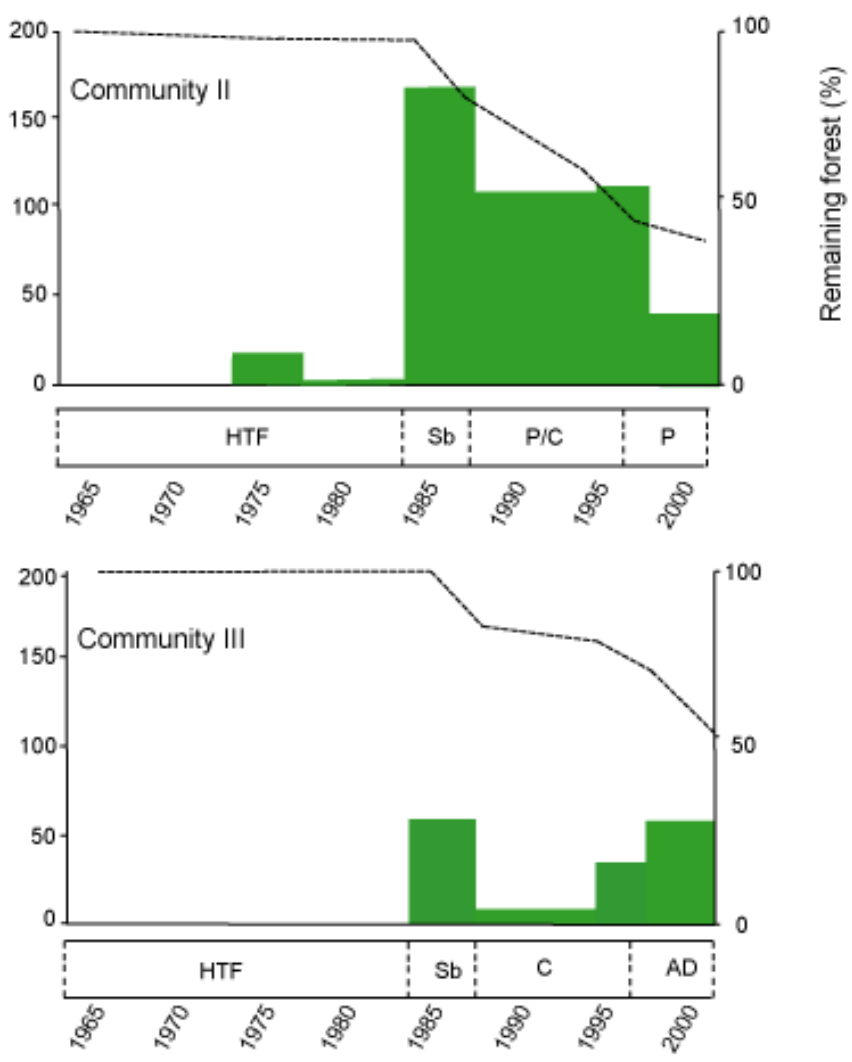
Fig. 3. A sequence of land-use maps illustrating a farm from Community III where conventional crops were grown throughout the period investigated.

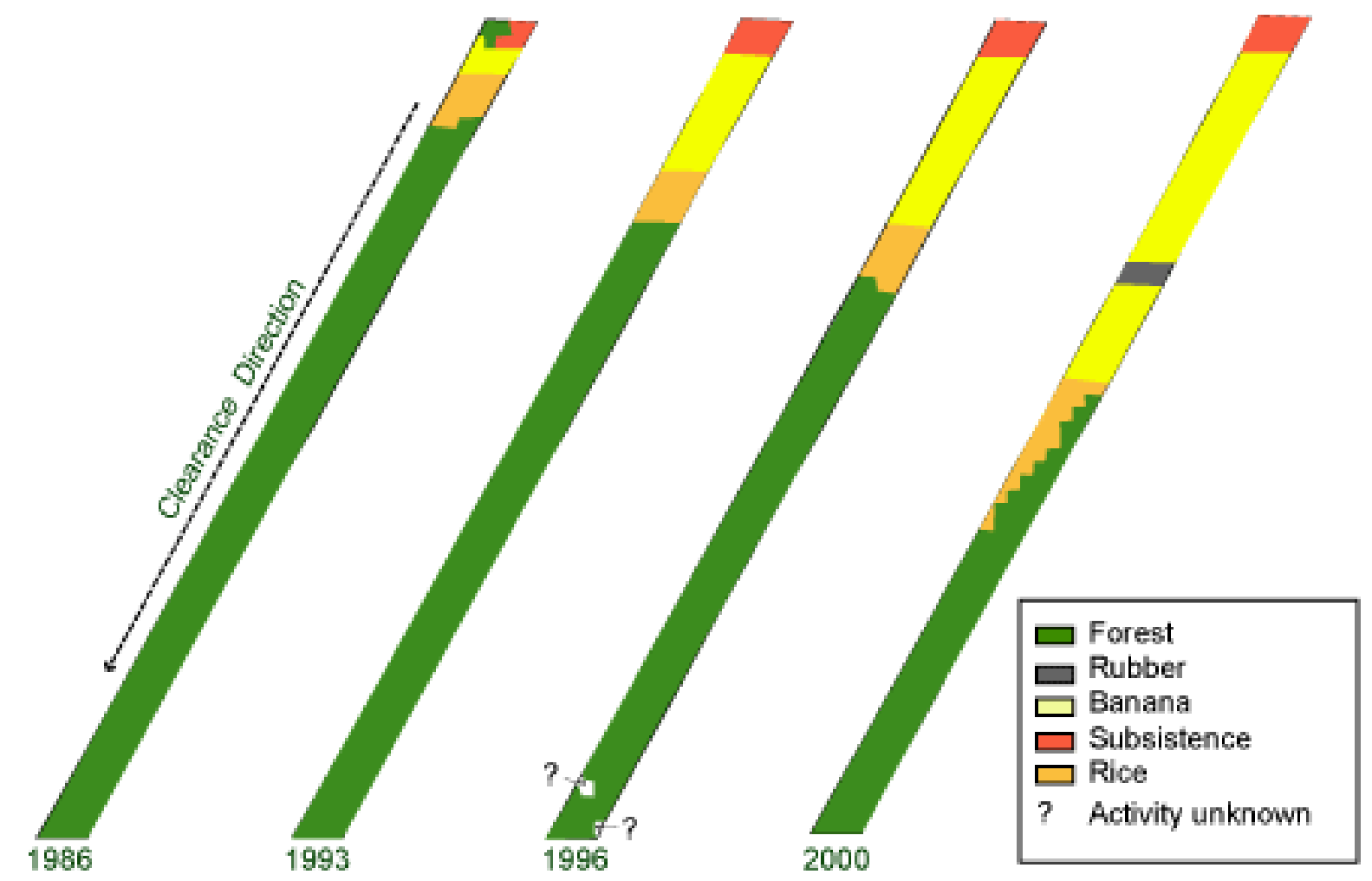

i.e., periods when coca prices were high and/or coca eradication was weakly enforced. It is at these times that deforestation rates have been low: mean forest losses on the farms we have studied have varied from negative values indicating forest regrowth to losses of around $0.4 \mathrm{ha} / \mathrm{yr}$. The economic arguments do not apply to the periods we term anti-coca regimes, times when the implementation of antinarcotics policies have overcome the economic imperatives of coca growing and forest conversion rates increased rapidly (mean forest clearance rates on farms range from $0.9-1.1 \mathrm{ha} / \mathrm{yr}$ ). Therefore, although Kaimowitz's (1997) and Henkel's (1995) economic arguments have some value in explaining deforestation rates in Chapare, they underplay the importance of policy shifts.

The impacts of changing policies on the areas of coca cultivated and eradicated, and substitute crops grown between 1980 and 2000, are shown in Fig. 6. Two communities-I and II-were settled before 1980, the approximate date when the global cocaine market became serviced by coca leaves from Chapare and the area cultivated increased markedly. Our evidence indicates that either rice or fruit were cultivated by farmers before 1980 and that relatively little coca was grown. The policy that drove land use in the 1960s was the Plan Decinal, but weak markets and a poor infrastructure led farmers to begin cultivating coca in large quantities from the late 1970s onward because of its comparative economic advantage and lack of government controls on its cultivation. During the 1980s, the existing farmed areas in Communities I and II, and the newly cleared areas in Community III, were dominated by coca. Eventually policies to counter the illicit coca trade were triggered (Tables 1 and 2 ). Despite moves to discourage cultivation between 
Fig. 4. A sequence of land-use maps illustrating a farm from Community I where coca was grown and then abandoned in favor of substitute crops.

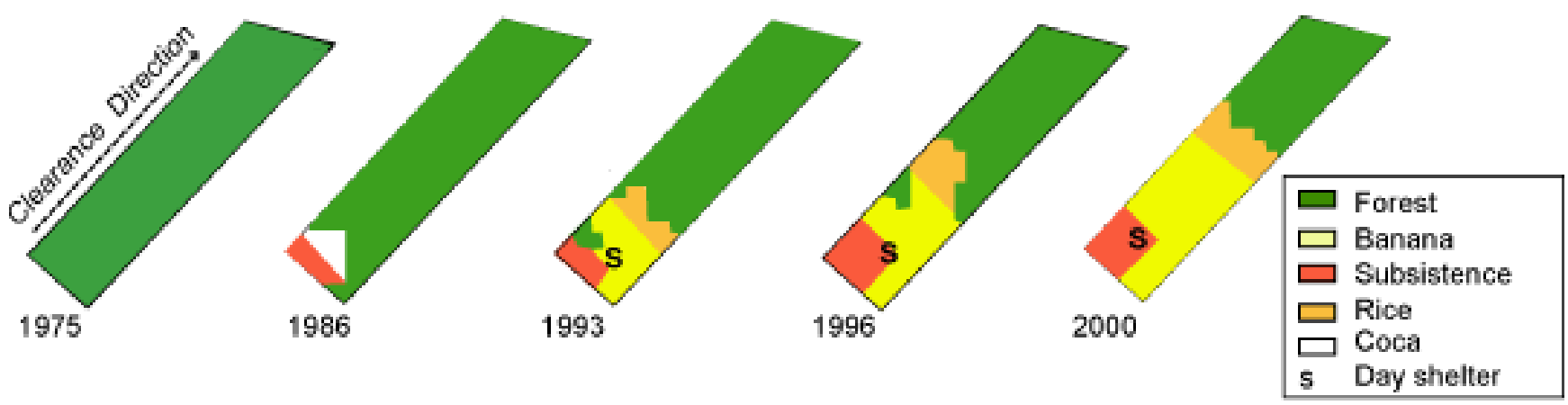

the mid 1980s and 1991, data in Fig. 6 clearly show that for the remainder of the 1980 s coca was dominant and the area under substitute crops only increased slowly. This trend is mirrored in the deforestation dynamics of the communities we researched. If the high rates of clearance for subsistence cultivation are ignored, the mean rates of forest conversion to agriculture across communities were low when coca was the main economic activity, e.g., Community I (-16.88 ha/yr) and Community III ( $8.2 \mathrm{ha} / \mathrm{yr})$. Community II maintained high rates because it is a predominantly cattle-rearing community, compared with field and orchard crop cultivation in the other two communities (Table 3), and clearance for pasture generates high rates of forest conversion.

Implementation of anti-coca policies strengthened significantly after 1986, and eventually the area under substitute crop programs increased, e.g., from 60000 to 120000 ha between 1993 and 2000 (Fig. $6)$. These broad land-use trends apply to all three communities. In Community I, fruit cultivation again became important, and in Community III, farmers began to cultivate bananas, black pepper, palm hearts, passion fruit, and pineapples. The responses are clearly evident in the mean community forest clearance rates, which increased to $30.98 \mathrm{ha} / \mathrm{yr}$ in Community I between 1993 and
1996, and 57.5 ha/yr in Community III after 1996. The situation in Community II-the cattle-rearing community-was different in that farmers had continued to clear large areas of forest for pasture, and during the implementation of anti-coca policies, overall community clearance rates remained high at over $100 \mathrm{ha} / \mathrm{yr}$.

By combining the economic and policy data with the analyses of deforestation dynamics at community and farm levels between the 1960s and 2003, we have identifed three epochs of colonist agriculture, each with a distinct deforestation dynamic. Epoch I was characterized by the cultivation of conventional tropical crops and is mainly restricted to the decades before 1980 . Deforestation rates were high, particularly in the initial few years when farmers were establishing their farms. In Epoch II, which extends throughout the 1980s and into the mid 1990s, land-conservative coca dominated agricultural practices and forest clearance rates plummeted. We call this the coca regime. From the mid 1990s to the end of our survey, Epoch III was characterized by the cultivation of alternatives to coca. During this time, land-hungry substitute crops necessitated the clearance of much forest and forest losses increased. This we term the anti-coca regime. 
Table 4. Proportion of interviewed farmers cultivating bananas, citrus, and coca, or ranching in the three communities investigated; and forest clearance statistics for all land parcels in the same communities. Interview data have been aggregated in 5-year intervals and related to the inter-image statistics. un $=$ denotes uncertain data due to less reliable recall by farmers interviewed.

\begin{tabular}{|c|c|c|c|c|c|c|c|c|c|}
\hline \multirow{2}{*}{ Community } & \multirow{2}{*}{ Time } & \multicolumn{3}{|c|}{$\begin{array}{l}\text { Major activities } \\
\text { (\% of interviewees) }\end{array}$} & \multirow{2}{*}{$\begin{array}{l}\text { Satellite image } \\
\text { interval }\end{array}$} & \multicolumn{3}{|c|}{$\begin{array}{l}\text { Average clearance rates } \\
\left({\left.\text { ha } \mathrm{yr}^{-1}\right)}^{\text {An }}\right.\end{array}$} & \multirow{2}{*}{$\begin{array}{l}\text { Average plo } \\
\text { area }\end{array}$} \\
\hline & & Coca & Banana & Citrus & & Community & Plot & SD & \\
\hline \multirow[t]{9}{*}{ I } & 1960-1965 & Un & Un & Un & & & & & \\
\hline & 1966-1970 & Un & Un & Un & 1963-1966 & 83.40 & 1.13 & 0.47 & 3.38 \\
\hline & $1971-1975$ & Un & Un & Un & & & & & \\
\hline & 1976-1980 & 0.00 & 50.00 & 0.00 & 1966-1975 & 63.92 & 0.71 & 0.40 & 9.88 \\
\hline & 1981-1985 & 0.00 & 57.14 & 7.14 & 1975-1986 & 43.46 & 0.48 & 0.36 & 14.55 \\
\hline & 1986-1990 & 21.43 & 50.00 & 14.29 & 1987-1993 & -16.88 & -0.2 & 0.36 & 12.18 \\
\hline & 1991-1995 & 28.57 & 50.00 & 14.29 & 1994-1996 & 30.98 & 0.32 & 0.54 & 13.12 \\
\hline & 1996-2000 & 21.43 & 57.14 & 35.71 & 1997-2000 & -44.32 & -0.45 & 0.63 & 11.33 \\
\hline & 2001-2003 & 7.14 & 78.57 & 71.43 & & $?$ & $?$ & & $?$ \\
\hline \multirow[t]{9}{*}{ II } & & Coca & Pasture & & & & & & \\
\hline & $1971-1975$ & Un & Un & & $1972-1975$ & 17.68 & 2.53 & 1.53 & 12.56 \\
\hline & 1976-1980 & Un & Un & & $1976-1983$ & 1.24 & 0.18 & 0.27 & 13.82 \\
\hline & $1981-1985$ & 37.50 & 6.25 & & 1983-1986 & 167.57 & 1.86 & 1.34 & 6.29 \\
\hline & 1986-1990 & 62.50 & 50.00 & & 1987-1993 & 108.41 & 1.19 & 0.76 & 13.45 \\
\hline & 1991-1995 & 31.25 & 75.00 & & 1994-1996 & 111.65 & 1.21 & 1.11 & 18.32 \\
\hline & 1996-2000 & 18.75 & 93.75 & & 1997-2000 & 39.83 & 0.47 & 1.42 & 20.21 \\
\hline & 2001-2003 & 12.50 & 93.75 & & & & $?$ & & $?$ \\
\hline & & Coca & Banana & & & & & & \\
\hline \multirow[t]{5}{*}{ III } & 1981-1985 & 23.08 & 0.00 & & 1983-1986 & 58.8 & 0.93 & 0.49 & 2.80 \\
\hline & 1986-1990 & 84.62 & 23.08 & & 1987-1993 & 8.20 & 0.14 & 0.21 & 3.80 \\
\hline & 1991-1995 & 61.54 & 53.85 & & 1994-1996 & 34.71 & 0.55 & 0.39 & 5.48 \\
\hline & 1996-2000 & 38.46 & 84.62 & & 1997-2000 & 57.50 & 0.92 & 0.52 & 9.16 \\
\hline & 2001-2003 & 38.46 & 92.31 & & & $?$ & $?$ & & $?$ \\
\hline
\end{tabular}


Table 5. Forest clearance typologies.

\begin{tabular}{|c|c|c|c|c|}
\hline \multirow[t]{2}{*}{ Trajectory } & \multirow[t]{2}{*}{ Description of land-use change and relative clearance rates } & \multicolumn{3}{|c|}{$\begin{array}{l}\text { Proportion of farms (as \%) following this } \\
\text { trajectory in Community: }\end{array}$} \\
\hline & & $\mathrm{I}^{\dagger}$ & II & III \\
\hline 1 & Coca cultivated throughout period researched; slow clearance & 0 & 6.3 & 7.7 \\
\hline 2 & $\begin{array}{l}\text { Coca never cultivated, other crops cultivated; fast clearance } \\
\text { [illustrated in Fig. 3] }\end{array}$ & 57.2 & 0 & 15.4 \\
\hline 3 & $\begin{array}{l}\text { Coca never cultivated, dominated by a rice-pasture rotation; } \\
\text { fast clearance }\end{array}$ & 14.3 & 31.2 & 0 \\
\hline 4 & $\begin{array}{l}\text { Coca cultivated, then abandoned in favor of substitute crops: } \\
\text { slow clearance replaced by fast clearance [illustrated in Fig. 4] }\end{array}$ & 21.4 & 0 & 76.9 \\
\hline 5 & $\begin{array}{l}\text { Predominantly ranching, but coca cultivated for part of period } \\
\text { researched, then abandoned in favor of ranching; generally fast } \\
\text { clearance }\end{array}$ & 0 & 62.5 & 0 \\
\hline 6 & $\begin{array}{l}\text { Commerical and subsistence cultivation prior to a period } \\
\text { dominated by coca cultivation, after which coca abandoned in } \\
\text { favor of substitute crops;: slow clearance during the coca } \\
\text { period, fast clearance at other times }\end{array}$ & 7.1 & 0 & 0 \\
\hline
\end{tabular}

${ }^{\dagger}$ We suggest that the low proportion of farmers admitting to growing coca is under-reported in Community I for two reasons. First, closer proximity to the main military base for narcotics control (Chimore) than the other two communities may have increased the farmers' sensitivity to coca growing - even in the past. Second, the presence our field assistant may have inhibited farmers because, even though he lives in the city of Cochabamba, he was known to people in this community through a church exchange.

Having, for the first time, quantified rates of forest conversion under coca and anti-coca regimes, it is possible to revisit the arguments postulated by Kaimowitz (1997) and Henkel (1995) about deforestation under both regimes. In terms of the household labor constraint argument, we have evidence from the sequences of forest/non-forest maps for individual farms contextualized with interview data. In the few areas where farmers continued to grow coca in the face of anti-coca policies (Trajectory 1,5), labor was directed toward coca and little was available to clear forest. Forest clearance rates on such farms were very low. More common is the property illustrated in Fig. 4, which is owned by a farmer who volunteered to give up coca and grow substitutes. Growing these proved to have lower labor requirements than tending coca bushes, and forest was cleared faster. Although the two examples lend some quantitative support to Kaimowitz's (1997) argument, it is difficult to evade the economic arguments that probably also prevailed in these two households. His argument is further weakened by evidence from Community II, the community where coca was always secondary to cattle. Here, long-term decisions were made to channel household labor into creating pasture so that herd sizes could be increased. When coca was cultivated in Epoch II, it was very much an income supplement. Typical is trajectory 3 (Table 5), which is restricted to farmers in Communities I and II who had cattle. High rates of forest conversion were maintained throughout Epoch II on these farms/ 
Fig. 5. Price data for coca leaves (top), pineapple (middle), and bananas (bottom) traded in Chapare. Data are from different sources, refer to text for details.
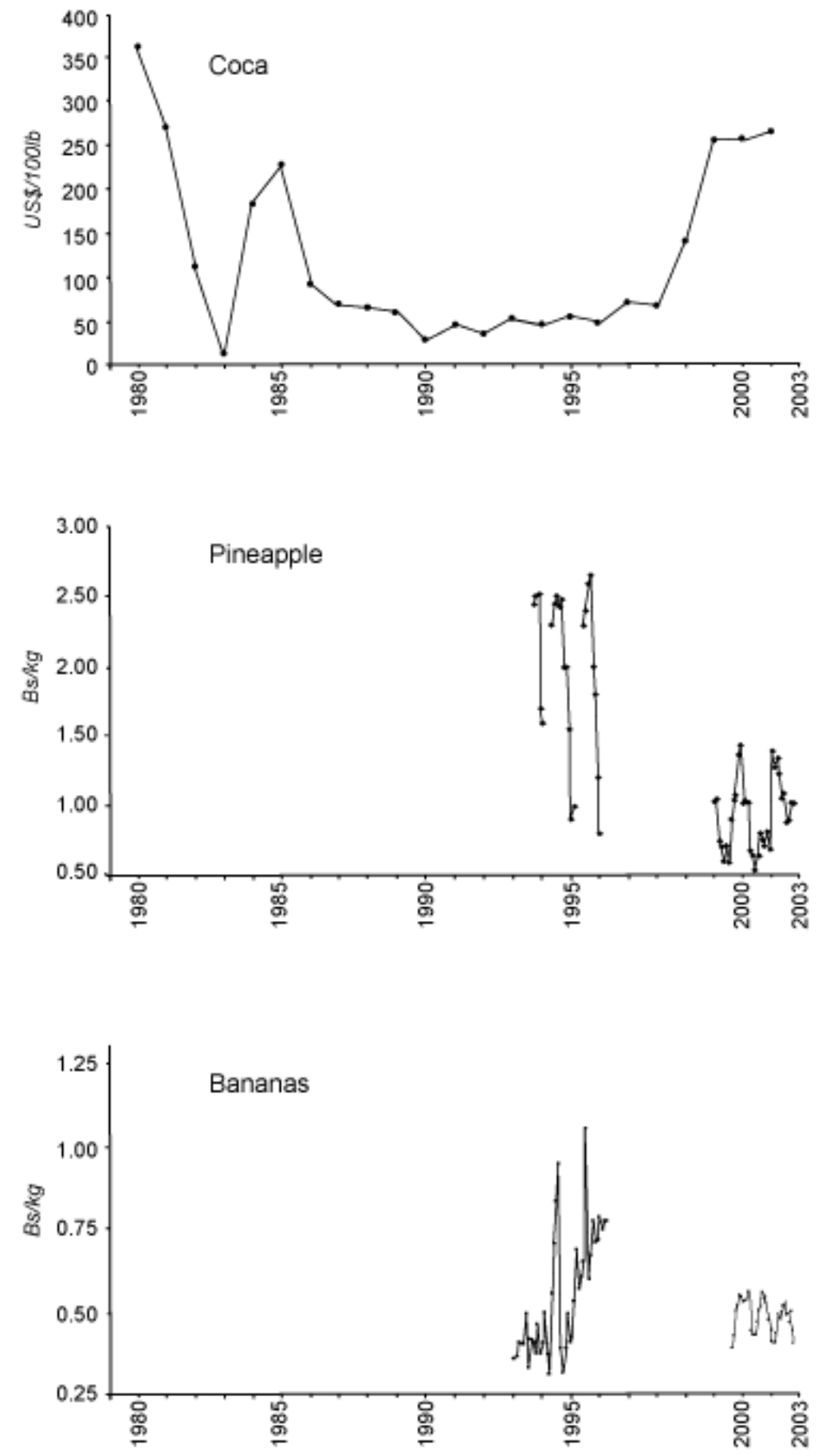
Table 6. Comparison of the economic returns from coca and heart of palm (source: interview data, 2000)

\begin{tabular}{lllll}
\hline \hline Crop & 2000 price (US\$) & $\begin{array}{l}\text { Potential number of } \\
\text { harvests annually }\end{array}$ & Potential harvest & $\begin{array}{l}\text { Selling return per } \\
\text { hectare of crop (2000 } \\
\text { prices), assuming three } \\
\text { harvests }\end{array}$ \\
\hline Coca & $\$ 98$ per carga & 3 & 4 cargas/cato & US\$ 2,352 \\
Heart of plam & $\$ 0.10$ per unit & 3 & 1500 units/ha & US\$ 150
\end{tabular}

$\dagger$ A carga is a colloquial term used for a 100-lb (45.4 kg) sack of dried coca leaves

$\ddagger$ A cato is $1 / 6^{\text {th }}(0.1 .67)$ ha, making the potential coca harvest $=1088 \mathrm{~kg} / \mathrm{ha}$.

ranches because of the long-term goal of building up herds. In Community I, the farm labor pool had been fully occupied cultivating conventional crops for almost two decades during Epoch I, during which time forest clearance rates were high. Clearance rates decreased in the mid to late $1980 \mathrm{~s}$ (Epoch II) because, although farmers grew conventional crops as well as coca, most household labor was diverted to coca cultivation. Labor resources were too stretched to clear more forest, but additionally our interviews indicate that simultaneously other factors promoted the decline in forest clearance rates. These were (i) that there was little or no forest left to clear in some plots; (ii) low yields had led farmers to abandon some crops leading to forest regrowth; and (iii) some citrus stands were maturing and appearing as forest regrowth on image-derived forest/non-forest maps. In places where farming activities were wellestablished and/or farmers had developed long-term strategies, e.g., in Communities I and II, we cannot readily attribute changes in forest clearance rates to household labor constraints created by the coca economy. The explanations underpinning changes in deforestation rates in such locales are more complex. In Community III, however, where the initial settlement coincided with the coca regime of Epoch II, there is a stronger case that the clearance rates were influenced by labor constraints.

The interviews provide strong support for Henkel's (1995) economic argument concerning forest clearance. Most farmers unambiguously confirmed that they had cleared more forest after they had given up coca (Epoch III) to achieve acceptable economic returns on investments in substitute crops and to maintain household incomes. Small areas of coca were grown during Epoch II, indicating that households dependent on coca were conservative deforesters. Enforcement of eradication and promotion of substitutes led to more forest being cleared, particularly among large families. In some circumstances, the image interpretation confirmed what the farmers suggested in interviews. For example, in Community III, where there was widespread replacement of coca with substitute crops, average farm sizes have increased by about 7 ha (in plots no larger than 20 ha) in Epoch III. This is much less than that predicted by Henkel, but we note that many farmers were cultivating coca alongside substitute crops until recently, and some possibly continue to do so. For those who chose substitutes over coca, the consumption of forest is all too clear from image analysis and walking through farms (Fig. 4). As already indicated, coca cultivation in Community II had little impact on the rate of forest-to-pasture conversion between Epochs I and II and farms continued to expand by approximately 1 ha/yr. In terms of Henkel's (1995) argument, the supplementary nature of coca in Community II is pertinent, but its location is also germane to the argument. Located in western Chapare, it was the community farthest away from the coca heartland of central Chapare. It is, perhaps, better thought of as being at the periphery of the well-established agricultural hinterland of Santa Cruz. Consequently markets were better developed and more stable, particularly for beef and dairy. 
Fig. 6. Areas of coca grown, coca eradicated, and substitute crops grown in Chapare, 1980-2000. The zero value for the amount of coca grown in 2000 is most likely related to propaganda at the time, rather than an actual value. (Sources: area of coca and substitute crops, Millington et al. 2003; eradication data, UNODC 2004)

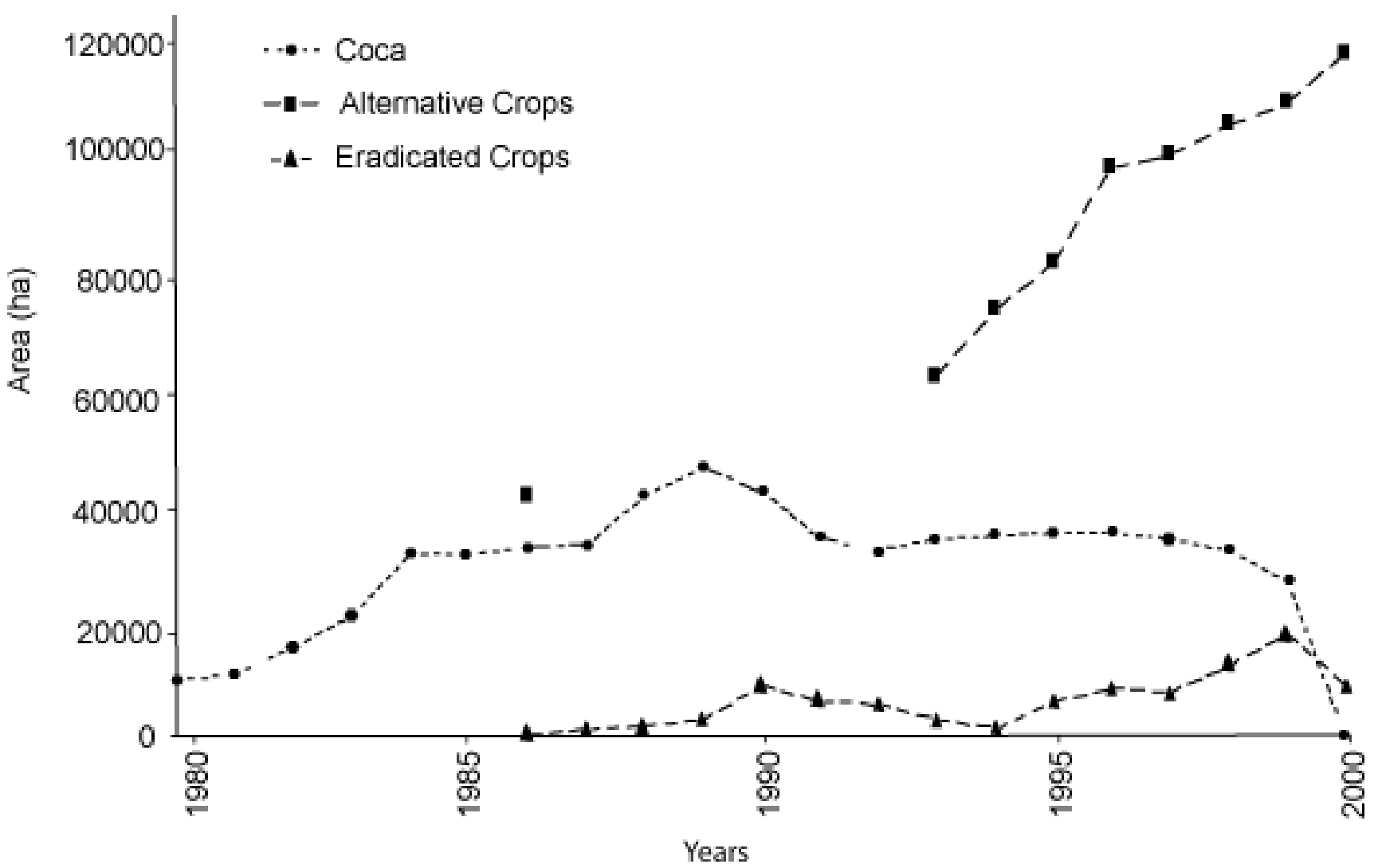

Although there is no documented meat price data for Chapare, farmers recalled that cattle prices were generally stable and rarely fluctuated through the 1980s and 1990s, eliminating one of the incentives to invest in coca. Even when the economic drivers encouraged farmers to cultivate coca elsewhere, long-term economic objectives seem to have prevailed in this community. In Community I, the rice and fruit cultivation system established before Epoch II never completely disappeared, even though forest clearance rates fell as more coca was cultivated. As a consequence, during Epoch III, farmers often reverted to their pre-coca crops and rates of clearance increased as either primary forest or forest regrowth was cleared.

\section{CONCLUSIONS}

We have integrated land-use mapping, interviews with farmers, and analyses of economic data and policy documents in a longitudinal analysis of deforestation dynamics in Chapare to quantify and understand the effects of coca cultivation and anticoca regimes. Focussing on three communities has enabled us to gain detailed insights into the socioeconomic processes underpinning the deforestation rates in three epochs: Epoch I before coca cultivation became widespread in Chapare and forest clearance was driven by the cultivation of subsistence crops, rice or fruit and pasture creation; Epoch II when coca cultivation was rampant; and Epoch III when eradication was strenuously enforced and substitute crop strategies promoted. 
The contrasting arguments of Kaimowitz (1997) that household labor constraints restrict forest losses during periods of coca cultivation-and Henkel (1995) - that the differences between economic returns from coca and substitute crops lead households to clear large amounts of forest after abandoning coca - are both partially supported by our findings. Low deforestation rates are typical of a coca regime, but are not simply a function of labor constraints. Farm incomes appear to have a strong influence. After coca is abandoned, deforestation rates increase. However, this is not a function of simple comparative economics undertaken by households. Complexities in household computations include the stability of markets for the substitutes, trends in farmgate prices, cropping patterns before switching to coca, and their ability to grow coca under conditions of enhanced surveillance.

The geography of place plays an important role in determining deforestation rates and this may be true for coca and anti-coca regimes in Chapare. Community II's relatively long distance from Chapare's coca heartland and its integration in a relatively stable market for meat in Santa Cruz meant that the effects of coca cultivation on deforestation rates between the three epochs outlined above were lower in Community II than in Communities I and III. Variations in soil and hydrological conditions have led to particular substitute crops being promoted in the zones where they grow best. Some communities prosper because they are located in zones where the dominant substitute crop they grow is also supported by stable markets and good prices. For others it may be the opposite, and they may return to coca. Deforestation rates will respond to these geographical variations.

Responses to this article can be read online at:

http://www.ecologyandsociety.org/voll3/iss 1/art31/responses/

\section{Acknowledgments:}

Research was funded by the European Union (Grant: ERB IC18CT980299), and a Slawson Award to AVB from the Royal Geographical Society (with Institute of British Geographers). We gratefully acknowledge data provided by El Centro de Investigacion y Desarollo Regional, Instituto Nacional de Reforma Agraria (cadastral plans) and Instituto Nacional de Estadísticas (all in
Cochabamba), USAID projects CORDEP and CONCADE, and the United Nations Office on Drugs and Crime. We benefited immensely from Felix Huanca Viraca (Universidad Mayor San Simon, Cochabamba) accompanying us in the field, and thank Indumathi Srinath for drawing the diagrams. Support for this publication was provided by NSF grant DEB-0731594.

\section{LITERATURE CITED}

Bradley, A. V. 2005. Land-use and land-cover change in the Chapare region of Bolivia. Dissertation, University of Leicester, UK.

Bradley, A. V., and A. C. Millington. 2008. Agricultural land-use trajectories in a cocaine source region: Chapare, Bolivia. Pages 231-250 in A. C. Millington and W. Jepson. Land change science in the Tropics. Springer, New York, New York, USA.

Bostwick, D., J. Dossey, J. Jones, J. A. Arrueta, C. Calla, and R. Laserna. 1990. Evaluation of the Chapare Regional Development project (CDRP). Pragma Corporation, Arlington, Virginia and Cochabamba, Bolivia.

Cardozo, S., O. Coca, and C. E. Yáñez. 1999. Cifras y datos del desarrollo alternativo en Bolivia. CEDEB, Cochabamba, Bolivia.

Commission of Enquiry on the Coca Leaf. 1949. Commission of Enquiry on the Coca Leaf. Bulletin on Narcotics 1949(1):20-41.

Crist, R. E. 1946. Bolivia-land of contrasts. American Journal of Economics and Sociology 2:297-325.

Dourojeanni, M. 1992. Environmental impact of coca cultivation and cocaine production in the Amazon region of Peru. Bulletin on Narcotics 1992 (2):37-53.

Edelmann, A. T. 1967. Colonization in Bolivia: progress and prospects. Inter-American Economic Affairs 20:39-54.

Etter, A., C. McAlpine, S. Phinn, D. Pullar, and H. Possingham. 2006. Unplanned clearing of 
Colombian rainforests: spreading like disease? Landscape and Urban Planning 77:240-254.

Fifer, J. V. 1967. Bolivia's pioneer fringe. Geographical Review 57:1-23.

Fjeldså, J., M. D. Álvarez, J.-M. Lazcano, and B. Leon. 2005. Illicit crops and armed conflict as constraints on biodiversity conservation in the Andes region. Ambio 34:205-211.

Hamandawana, H., R. Chanda, and F. Eckardt. 2007. The role of human factors in and around the Okavango Delta, Botswana. International Journal of Environmental Studies 64:587-603.

Hellin, J. 2001. Coca eradication in the Andes: lessons from Bolivia. Capitalism Nature Socialism 12:139-157.

Henkel, R. 1987. The Chapare project. A study of directed colonization in the Bolivian Tropics. Unpublished manuscript. Arizona State University, Tempe, Arizona, USA.

Henkel, R. 1995. Coca (Erthroxylum coca) cultivation, cocaine production, and biodiversity loss in the Chapare region of Bolivia. Pages 551560 in S. P. Churchill. Biodiversity and conservation of neotropical montane forests. Proceedings of the Neotropical Montane Forest Biodiversoty and Conservation Symposium, New York, 21-26 June 1993. Springer, Dordrecht, The Netherlands.

Jackson, D. R., D. D. Bathrick, P. A. Martin, and D. Rodriguez-Schneider. 2003. Final report. Assessment of the USAID/Bolivia alternative development strategy. Development Associates, Incorporated, Arlington, Virginia, USA.

Joseph Rowntree Foundation. 2000. Drugs; dilemmas and choices and the law. [online] URL:

http://www.jrf.org.uk/knowledge/findings/foundations/ pdf/N70.pdf.

Kaimowitz, D. J. 1997. Factors determining low deforestation: the Bolivian Amazon. Ambio 26:536-40.

Lavandez, J. 1925. La colonización en Bolivia durante la primera centuria de su independencia. Intendencia de Guerra, La Paz, Bolivia.
Liverman, D., E. F. Moran, R. R. Rindfuss, and P. C.Stern. 1998. People and pixels. Linking remote sensing and social science. National Academy Press, Washington, D.C., USA.

MacGregor, F. E. 1993. Coca and cocaine: an Andean perspective. Greenwood Press, Westport, Connecticut, USA.

Mäki, S., R. Kalliola, and K. Vuorinen. 2002. Road construction in the Peruvian Amazon: processes, causes and consequences. Environmental Conservation 28:199-214.

Mather, K. F. 1922. Exploration in the land of the Yuracares, eastern Bolivia. Geographical Review 12:42-56.

McCoy, A. W. 2004. The stimulus of prohibition: a critical history of the global narcotics trade. Pages 104-114 in M. K. Steinberg, J. J. Hobbs, and K. Mathewson. Dangerous harvest, drug plants and the transformation of indigenous landscapes. Oxford University Press, Oxford, UK.

McCracken, S. D., E. S. Brondizio, D. Nelson, E. F. Moran, A. D. Siqueira, and C. RodriguezPedraza. 1999. Remote sensing and GIS at farm property level: demography and deforestation in the Brazillian Amazon. Photogrammetric Engineering and Remote Sensing 65:1311-1320.

Meruvia, F. 2000. Historia de la coca. Los Yungas de Pocona y Totora (1550-1900). Plural, La Paz, Bolivia.

Millington, A. C., and A. V. Bradley. 2008. Developing a thick understanding of forest fragmentation in landscapes of colonization in the tropics. Pages 124-137 in R. W. Aspinall and M. Hill. Land use change: science, policy and management. Taylor and Francis, London, UK.

Millington, A. C., X. M. Velez-Liendo, and A. V. Bradley. 2003. Scale dependence in multitemporal mapping of forest fragmentation in Bolivia: implications for explaining temporal trends in landscape ecology and applications to biodiversity conservation. ISPRS Journal of Photogrammetry and Remote Sensing 57:289-299.

Montes de Oca, I. 1989. Geografia y recursos naturales de Bolivia. Academia Nacional de Ciencias de Bolivia, La Paz, Bolivia. 
Morales, W. Q. 2004. A brief history of Bolivia. Checkmark Books, New York, New York, USA.

Moran, E., E. S. Brondizio, P. Mausel, and Y. Wu. 1994. Integrating Amazonian vegetation, land-use, and satellite data. Bioscience 44:329-338.

Myers, N. 1988. Threatened biotas: 'hotspots' in tropical forests. The Environmentalist 8:187-208.

Myers, N. 2003. Biodiversity hotspots revisited Bioscience 53:917-917.

Myers N., R. A. Mittermeier, C. G. Mittermeier, G. A. B. da Fonseca, and J. Kent. 2000. Biodiversity hotspots for conservation priorities. Nature 403:853-858.

Naughton-Treves, L. 2004. Deforestation and carbon emissions at tropical frontiers: a case study from the Peruvian Amazon. World Development 32:173-190.

Navarro, G., W. Ferreira, C. Antezana, S. Arrázola, and R. Vargas. 2004. Bio-corredor amboró madidi zonificación ecológia. Editorial FAN, Santa Cruz, Bolivia.

Ortuño F. S. 2002. El rostro del dessarollo alternativo. Caso tropico de Cochabamba-Bolivia, 1984-2002. IESE, Cochabamba, Bolivia.

Pan, W. K. Y., S. J. Walsh, R. E. Bilsborrow, B. G. Frizzelle, C. M. Erlien, and F. Baquero. 2004. Farm-level models of spatial patterns of land use and land cover dynamics in the Ecuadorian Amazon. Agriculture, Ecosystems and Environment 101:117-134.

Parreiras, D. 1961. Data on the illict traffic in cocaine and coca leaves in South America, with an annex on narcotics control in Brazil. Bulletin on Narcotics 1961(Issue 4):33-36.

Rindfuss, R. R., P. Prasartkul, S. J. Walsh, B. Entwisle, Y. Sawangee, and J. B. Vogler. 2003. Household-parcel linkages in Nang Rong, Thailand: challenges of large samples. Pages 131172 in J. Fox, R. R. Rindfuss, S. J. Walsh, and V. Mishra People and the environment: approaches to linking household and community surveys to remote sensing and GIS, Kluwer Academic Publishers, Boston, Massachusetts, USA.
Rivera, A. 1990. Diagnostico socio económico de la poblacíon de Chapare. Central de Estudias de Realidad Economía y Social (CERES), Cochabamba, Bolivia.

Rodríguez, A. A. 1965. Possibilities for crop substitution for coca bushes in Bolivia. Bulletin on Narcotics 1965(Issue 3): 13-23.

Sanabria, H. 2004. The state and the ongoing struggle over coca in Bolivia: legitimacy, hegemony, and the exercise of power. Pages 153166 in M. K. Steinberg, J. J. Hobbs, and K. Mathewson. Dangerous harvest, drug plants and the transformation of indigenous landscapes. Oxford University Press, Oxford, UK.

South, R. B. 1977. Coca in Bolivia. Geographical Review 67:22-33.

Steinberg, M. K., J. J. Hobbs, and K. Mathewson. 2004. Dangerous harvest, drug plants and the transformation of indigenous landscapes. Oxford University Press, Oxford, UK.

Steininger, M. K., C. J. Tucker, J. R. G. Townshend, T. J. Killeen, A. Desch, V. Bell, and P. Ersts. 2002. Tropical deforestation in the Bolivian Amazon. Environmental Conservation 28: $127-134$.

Tappan, G. G., E. C. Hadj, E. C. Wood and R. W. Leitzow. 2000. Use of Argon, Corona, and Landsat imagery to assess 30 years of land resource changes in west-central Senegal. Photogrammetric Engineering and Remote Sensing 66:727-735.

United Nations Office of Drug and Crime (UNODC). 2004. Bolivia coca cultivation survey. UNODC, Vienna, Austria.

United Nations Office of Drug and Crime (UNODC). 2006. Bolivia: coca cultivation survey, June 2005. UNODC, New York, New York, USA.

van Gils, H. A. M. J. and A. V. Loza Armand Ugon. 2007. What drives tropical deforestation in Carrasco Province, Bolivia? Ambio 35:81-85.

Viña, A., F. Echavarria, and D. C. Rundquist. 2004, Satellite change detection analysis of deforestation rates and patterns along the Colombia-Ecuador border. Ambio 33:118-125. 
Walker, R. 2004. Mapping process to pattern in the landscape change of the Amazonian frontier. Annals of the Association of American Geographers 93:376-398

Walsh J. M. 2004. Are we there yet? Measuring progress in the U.S. war on drugs in Latin America. Drug War Monitor, December 2004. Washington Office on Latin America, Washington, D.C., USA.

Walsh, S. J., R. E. Bilsborrow, S. J. McGreagor, B. G. Frizelle, J. P. Messina, W. K. T. Pan, K. A. Crewes-Meyer, G. M. Taff, and F. Baquero, F. 2003. Integration of longitudinal surveys, remote sensing time series and spatial analyses: approaches for linking people and place. Pages 91-130 in J. Fox, R. R. Rindfuss, S. J. Walsh, and V. Mishra. People and the environment: approaches to linking household and community surveys to remote sensing and GIS. Kluwer Academic Publishers, Boston, Massachusetts, USA.

Weeks, D. 1946. Bolivia's agricultural frontier. Geographical Review 36:546-567.

Weil, C. 1983. Migration among landholdings by Bolivian campesinos. Geographical Review 73:182-193.

Weil, C., and Weil, J. 1983. Government, campesinos and business in the Chapare: a case study of Amazon occupation. Inter-American Economic Affairs 36:29-36

Young, K. 1996. Threats to biological diversity caused by coca/cocaine deforestation. Environmental Conservation 23:7-15.

Young, K. 2004. Environmental and social consequences of coca/cocaine in Peru. Policy alternatives and a research agenda. Pages 249-273 in M. K. Steinberg, J. J. Hobbs, and K. Mathewson. Dangerous harvest, drug plants and the transformation of indigenous landscapes. Oxford University Press, Oxford, UK. 